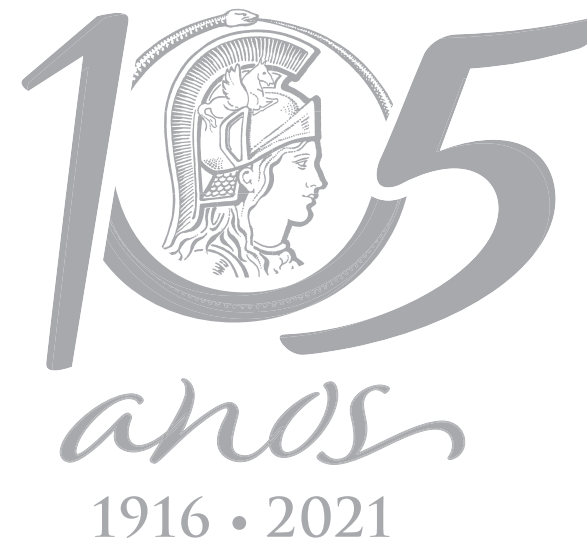

$1916 \cdot 2021$

\title{
ECOSYSTEMS
}

\section{The first record of Centrocestus formosanus (Trematoda: Heterophyidae) in southern Brazil supported by molecular data}

\author{
JULIANA R.M. CICCHETO, BRUNO H.M. STABILE, THOMAZ M.C. FABRIN, \\ ALESSANDRA V. DE OLIVEIRA, RICARDO M. TAKEMOTO \& RODRIGO J. DA GRAÇA
}

\begin{abstract}
Centrocestus formosanus is a digenean parasite first described from Asia, which parasitizes Melanoides tuberculata (Gastropoda: Thiaridae) at the first intermediate stage, and different fish species as second intermediate host. C. formosanus was previously recorded in Brazilian states, but never before in the southern region of this country. Recording and identification of digenean species through morphological identification is a taxonomic challenge. In light of this, we use an integrative taxonomic approach to report the occurrence of cercariae and metacercariae of $\mathrm{C}$. formosanus in molluscs and fish, respectively, in an urban park located in southern Brazil. Specimens of M. tuberculata and the fishes Poecilia reticulata and Xiphophorus sp. (Poeciliidae) were collected for screening for parasites and molecular analyses using partial fragments of the $28 \mathrm{~S}$ rDNA gene. The identification of $\mathrm{C}$. formosanus obtained from molluscs and fish specimens permitted us to partially solve the life cycle of this parasite for the first time in the studied environment, demonstrating the necessity of monitoring and controlling molluscs populations. Nevertheless, our results will support future studies aiming to elucidate the life-cycle of $C$. formosanus in this region, since all sampled hosts' species are invasive in this environment.
\end{abstract}

Key words: Digenea, zoonotic potential, integrative taxonomy, $28 \mathrm{~S}$ rDNA, Thiaridae.

\section{INTRODUCTION}

Melanoides tuberculata (Müller, 1774) (Gastropoda: Thiaridae) is a freshwater gastropod occurring in lentic and lotic environments in Asia and East Africa (Cheng \& Malek 1974, PaulaAndrade et al. 2012). In Brazil, this species was introduced in the 1960s, and was first recorded in Santos city, São Paulo State (Vaz et al. 1986), and since then in other regions of this country (Fernandez et al. 2003, Coelho et al. 2018).

Melanoides tuberculata is recognized as an intermediate host of at least 37 species of trematodes around the world, 11 of which have zoonotic potential (Ben-Ami \& Heller 2005, Pinto \& Melo 2011). In the Americas, four species of trematodes were identified in M. tuberculata: Centrocestus formosanus (Nishigori, 1924) (Heterophyidae), Haplorchis pumilio (Looss, 1896) (Heterophyidae), Philophthalmus gralli Mathis \& Leger, 1910 (Philophthalmidae) and Renicola sp. Cohn 1904 (Renicolidae) (Pinto \& Melo 2011, 2013). Among these, C. formosanus has a wide distribution, recorded from many countries, including India, Japan, China, Mexico, Italy, Colombia, Croatia, Thailand, Costa Rica, United States, Vietnam, Lao People's Democratic Republic, Turkey, Philippines and Egypt (Komiya \& Suzuki 1966, Rekharani \& Madhavi 1985, Chen et al. 1991, Tampieri et al. 1999, Salgado-Maldonado et al. 2005, Mitchell et al. 2005, Velásquez et 
al. 2006, Gjurčević et al. 2007, Han et al. 2008, Chuboon \& Wongsawad 2009, Cortés et al. 2009, De \& Le 2011, Chai et al. 2013, McDermott et al. 2015, Yousif et al. 2016).

In Brazil, C. formosanus was recorded in molluscs in Minas Gerais, Rio Grande do Norte, Brasília and Rio de Janeiro (Pinto \& Melo 2010, 2012b, Paula-Andrade et al. 2012, Ximenes et al. 2016). Studies carried out in Goiás (Pinto et al. 2013) and Rio de Janeiro States (Thiengo et al. 2001, Boaventura et al. 2002, Bogéa et al. 2005) reported only the occurrence of the larval stage identified as pleurolophocercous cercariae, and it was not possible to identify these to species level. Pinto \& Melo (2010), Paula-Andrade et al. (2012), and Ximenes et al. (2016) carried out experimental infections for the study of the life cycle. Additionally, other studies contributed to understanding the damages caused by C. formasanus to its definitive hosts, mainly related to the immune system and susceptibility to worms (Chen 1942, Mati et al. 2013).

These parasites have molluscs as their first intermediate host, and fish or amphibians as second intermediate host (Han et al. 2008). The definitive host varies from piscivorous birds to mammalian species, as well as humans, presenting zoonotic potential (Chen 1942, Pinto \& Melo 2010). In different hosts, C. formosanus is characterized morphologically by a double crown of acicular spines composed of 26-36 spines in the oral suction cup (Pinto \& Melo 2010, Yousif et al. 2016), and the identification of species belonging to Centrocestus depends on the number of spines on the oral sucker (Yousif et al. 2016).

Records about the occurrence of a parasite in a region represent a taxonomic challenge while solving its life cycle and stages are important for public health policies (Chen 1942, Esch et al. 2002). Using only the traditional taxonomy can be controversial since many morphological characters could be subjective because of sampling methods, coloration techniques, and variation of morphological structures because of methods used during microscope slide preparation. The use of molecular data only can be challenging since the DNA extraction can be difficult, as well as tissue obtention, and some groups present a small amount of molecular data available in public databases. Thus, the use of morphological and molecular data allows a more assertive identification considering an integrative taxonomy approach (Perkins et al. 2011, Chen et al. 2011). In this sense, the molecular characterization can be helpful during the identification of different groups of organisms, including digeneans, that are difficult to characterize morphologically during intermediate life stages (Pavanelli et al. 2002, Olson \& Tkach 2005).

This study aimed to record the occurrence of centrocestus formosanus using morphological and molecular analyses, investigating possible intermediate hosts obtained in an urban park.

\section{MATERIALS AND METHODS}

\section{Collection}

Melanoides tuberculata $(n=57)$, Poecilia reticulata Peters, 1859 ( $n=52$ ) and Xiphophorus sp. Heckel, 1848 ( $n=2$ ) were collected between August and November 2018, totalizing three samplings. The collection sites were ponds "Gruta da Santa" and "Jardim Japonês" (23은'29"S, 51ㅇ5'48"W), at Parque do Ingá, an urban park considered as a conservation area in Maringá city, Paraná, Brazil, also used for recreation by local and regional population. Fish and molluscs were collected using landing nets. M. tuberculata and P. reticulata were collected in all samplings, while Xiphophorus sp. was collected only in one of the three samplings. All specimens were transported to the Laboratório de Ictioparasitologia of the 
Núcleo de Pesquisas em Limnologia, Ictiologia e Aquicultura (Nupélia) of the Universidade Estadual de Maringá (UEM); specimens obtained were maintained in an aquarium for subsequent examination. These fishes species were analyzed because they were the main species collected during a short-term monitoring program carried out in this environment.

During screening for parasites, molluscs were eviscerated to remove the digestive gland, used as an infection site by cercariae; fish were screened in the branchial arch, used as an infection site by metacercariae. Cercariae and metacercariae found were morphologically identified previously according to Pinto \& Melo (2010) and individually separated for subsequent DNA extraction.

All the procedures were approved by the Ethics Committee on Animal Use from the Universidade Estadual de Maringá (protocol CEUA 8244220618) and by the environmental council of Maringá, Paraná, Brazil (32520/2018).

\section{Molecular analyses}

The DNA extraction was carried out using the ReliaPrep ${ }^{\mathrm{TM}}$ gDNA Tissue Miniprep System (Promega'M) kit, according to the manufacturer's instructions. Polymerase chain reactions (PCR) were carried out in an Applied Biosystems Proflex PCR (Life Technologies) thermocycler, with the final volume of reactions of $20 \mu \mathrm{L}$, containing Tris- $\mathrm{KCl}$ [20mM Tris- $\mathrm{HCl}$ ( $\mathrm{pH} 8.4)$, $50 \mathrm{mM} \mathrm{KCl}, \mathrm{MgCl}_{2}$ (1.87 mM), primers (2.5 pmoles), dNTPs: dATP, dCTP, dGTP and dTTP (0.5 mM), Taq Polymerase Platinum - Invitrogen ${ }^{\mathrm{TM}}$ (1 U), DNA template $(3 \mu \mathrm{L})$ and ultrapure water q.s. $20 \mu \mathrm{L}$.

Following primers were used in the PCR reactions of the $28 \mathrm{~S}$ rDNA gene, responsible by the large subunit (LSU) of the ribosome, U178 (5'GCA CCC GCT GAA YTT AAG-3') and L1642 (5'CCA GCG CCA TCC ATT TTC A-3') (Lockyer et al. 2003), considering following conditions: initial denaturation at 94 oC for $5 \mathrm{~min}$, followed by 30 cycles at 94 o C for $30 \mathrm{~s}, 56$ o $\mathrm{C}$ for $1 \mathrm{~min}$, and 72 oC for $1 \mathrm{~min}$; and a final cycle at 72 o C for $5 \mathrm{~min}$ (modified from Graça et al. 2018). Amplicons were visualized in an electrophoresis gel (1\%) and purified with polyethylene glycol 8000 (Rosenthal et al. 1993). Sequencing reactions were prepared using the BigDye ${ }^{\mathrm{TM}}$ Terminator $\mathrm{v} 3.1 \mathrm{kit}$ and sent to an automated sequencer ABI 3500 Applied Biosystems $^{\mathrm{TM}}$, at the Complexo de Centrais de Apoio à Pesquisa (COMCAP) at the Universidade Estadual de Maringá. Sequences were visually edited and aligned using BioEdit (Hall 1999) and MEGA 7 (Kumar et al. 2016) software, respectively, and compared to sequences available previously in GenBank using the BLASTn tool <http://blast. ncbi.nlm.nih.gov/Blast.cgi>. Sequences obtained in this study were deposited in GenBank (MK876840-MK876845).

\section{RESULTS}

Among all specimens of $M$. tuberculata, only one was parasitized by cercariae (1.8\%) and were morphologically classified as pleurolophocercous (Figure 1a). These cercariae present spherical eyespots on the body, a ventral sucker and an oral sucker with spines surrounding it, pharynx, penetration glands, rostellar hooks, genital primordium and a tail, with finfolds throughout tail and body. Metacercariae were obtained in all individuals of Xiphophorus sp. $(n=2)$ and four individuals of $P$. reticulata $(7.7 \%$ ) (Figure $1 \mathrm{~b}-\mathrm{d}$ ). The metacercariae has a visible oral sucker with two rows armed with spines.

The partial fragments of the $28 \mathrm{~S}$ gene presented $732 \mathrm{bp}$ and were obtained from six specimens of parasites (three cercariae and three metacercariae). All sequences were identical and confirmed the identification of Centrocestus 

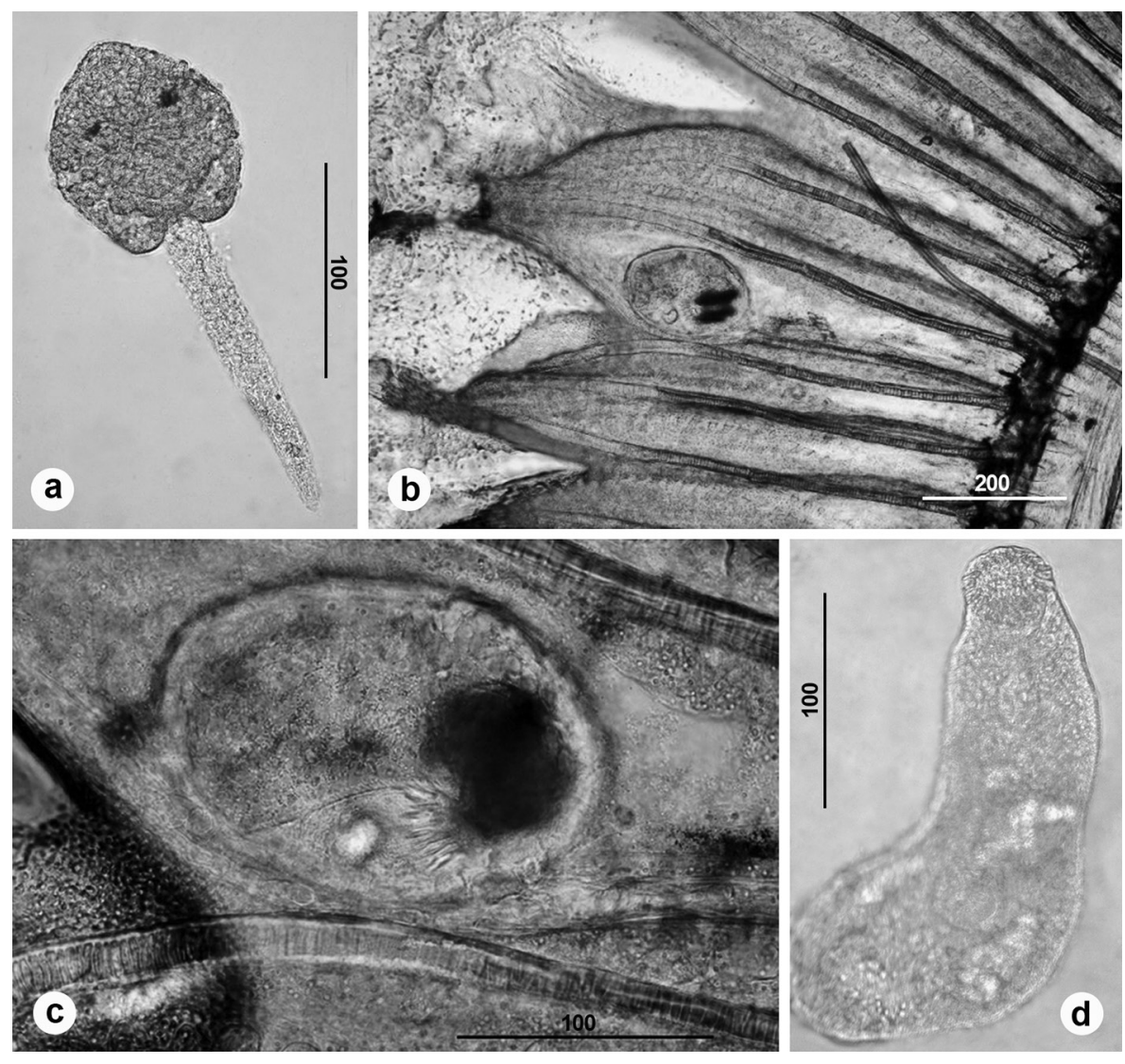

formosanus with $100 \%$ similarity when compared to sequences obtained from GenBank (a total of 8 sequences of $C$. formosanus), using BLASTn tool, considering the partial fragment obtained in this study. Of the sequences data compared with those generated by our study, four were obtained during the adult stage of development (KY075663, KY075664, KY075665 and HQ874609), three during the cercaria stage of development (MG738251, KY369153 and KY351633), and one sequence during the metacercaria stage of development (KY369154) (Supplementary Material - Table SI).

\section{DISCUSSION}

Our study is the first record of $C$. formosanus in the southern region of Brazil parasitizing M. tuberculata and poeciliid fish. In Brazil, metacercariae of this parasite were recorded in

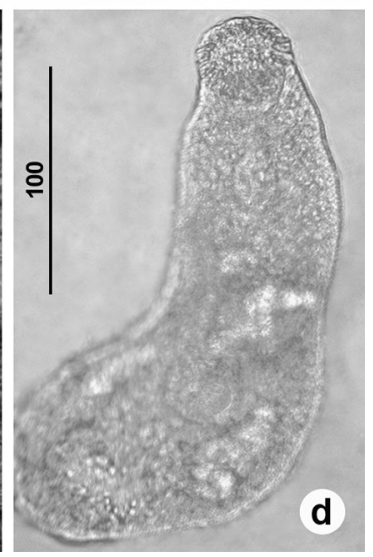

Figure 1. Centrocestus formosanus (a) Cercaria obtained from Melanoides tuberculata collected in Parque do Ingá, Maringá. (b) Gills of Poecilia reticulata infected with metacercaria. (c) Metacercaria obtained from the gills of Poecilia reticulata. (d) Metacercaria out of the cyst. Obs.: scale in $\mu \mathrm{m}$. 413×387mm (95 x 95 DPI).

Poecilia reticulata, Australoheros facetus (Jenyns, 1842) and Oreochromis niloticus (Linnaeus, 1758) (both Cichlidae), all in Minas Gerais State (Pinto \& Melo 2012a, b, Pinto et al. 2014). In other countries, C. formosanus was identified in $\mathbf{4 0}$ species of fish which can act as an intermediate hosts (Martin 1958, Salgado-Maldonado et al. 1995). Various possible intermediate hosts can be economically important, for example, Ctenopharyngodon idellus Valenciennes, 1844 (Cyprinidae), Cyprinus carpio Linnaeus, 1758 (Cyprinidae), Ictalurus punctatus (Rafinesque, 1818) (Ictaluridae), Hypophthalmichthys molitrix (Valenciennes, 1844) (Cyprinidae), Megalobrana amblycephala (Yih, 1955) (Cyprinidae), Mylopharyngodon piceus (Richardson, 1846) (Cyprinidae), Oreochromis aureus (Steindachner, 1864) (Cichlidae) (Scholz \& Salgado-Maldonado 2000). Fish parasitized by C. formosanus may have their development affected, showing 
fitness reduction or even lethal effects, due to histological modifications which result in hyperplasia, hyperemia and congestion (Martin 1958, Vélez-Hernández et al. 1998, Mitchell et al. 2000, Piazza et al. 2006, Tolley-Jordan \& Chadwick 2012, Pinto et al. 2014). Thus, the presence of these parasites in fish farms requires financial and management efforts, including spending on specialists and products used to control the infection, causing economic loss (Mitchell et al. 2005, Tavechio et al. 2009).

Fishes obtained in our study (Poeciliidae) were introduced to control mosquitoes' vectors of different diseases (Araújo et al. 2009) and are invasive species, as well as $M$. tuberculata Invasive species can facilitate the introduction of non-specific parasites resulting in economic losses, besides the threatens to the conservation, as diseases in different fish species (Huston et al. 2014, McDermott et al. 2015, Sumuduni et al. 2018).

These fishes are not commonly consumed by the local population, because of their reduced size and usefulness as aquarium fish. However, different birds' species can eat them and be infected by metacercariae, contributing to the development of the parasite to the adult stage, transmitting the eggs of this parasite to other fish through infected feces (Thatcher 1993, Takemoto et al. 2004). Digenean transmission can also occur during birds migration, promoting the dispersion of infectious diseases in aquatic ecosystems (Rząd \& Busse 2015, Sánchez et al. 2018) indicating that aquatic and wading birds could be the main animals transmitting Trematodes (Fredensborg et al. 2006).

Some birds were already recorded infected with C. formosanus, as Bubulcus ibis coromandus Boddaert, 1783 (Ardeidae), Butorides striata Linnaeus, 1758 (Ardeidae) and Nycticorax nycticorax Linnaeus, 1758 (Ardeidae) (Pinto \& Melo 2010). The monitoring data of the Parque do Ingá (Maringá 2007) recorded Butorides striata, and could be a candidate to the definitive host of $C$. formosanus in this environment, and this species presents a migratory behavior (Brum et al. 2016). Among the species occurring in the Parque do Ingá, future investigations are necessary considering the feeding habits of different birds, as Aramides saracura Spix, 1825 (Rallidae), Ardea alba Linnaeus, 1758 (Ardeidae), Egretta thula Molina, 1782 (Ardeidae), Megaceryle torquata Linnaeus, 1766 (Alcedinidae), Nannopterum brasilianus Gmelin, 1789 (Phalacrocoracidae) and Pitangus sulphuratus Linnaeus, 1766 (Tyrannidae), since eventually they could serve as host of $C$. formosanus.

In addition to harming fish in natural and aquaculture environments, C. formosanus also is considered zoonotic, using humans as a definitive host (Chai et al. 2013). Infections were recorded in humans that consume raw fish meat in various countries, as Taiwan (Nishigori 1924), China (Chen et al. 1991), Vietnam (De \& Le 2011) and Lao People's Democratic Republic (Chai et al. 2013). However, these studies did not show the pathogenicity degree in their hosts (Chai et al. 2013). Nevertheless, experimental infections using mice as a model and other Centrocestus species showed intestinal alterations including villous atrophy and hyperplastic crypt (Hong et al. 1997).

The presence of $\mathrm{C}$. formosanus in Maringá city supports the importance of studies about the parasitic fauna in fish, especially species presenting zoonotic potential. Additionally, the prevalence shown in our results could correspond to more infected hosts, so the introduction of species such as C. formosanus and $M$. tuberculata may have impacts on local fauna; $M$. tuberculata was the first time recorded in this environment too. In this sense, using an integrative taxonomy approach (Dayrat 2005) 
enables solving life cycles of digenean species, particularly those presenting health risks and potentially zoonotic, besides allowing the correct identification of parasites using morphological and molecular approaches.

\section{Acknowledgments}

The authors acknowledge the support and infrastructure of the Núcleo de Pesquisas em Limnologia, Ictiologia e Aquicultura of the Universidade Estadual de Maringá (NUPÉLIA-UEM) and the financial support of Conselho Nacional de Desenvolvimento Científico e Tecnológico (CNPq) (446150/2014-2) and Coordenação de Aperfeiçoamento de Pessoal de Nivel Superior (CAPES).

\section{REFERENCES}

ARAÚJO FG, PEIXOTO MG, PINTO BCT \& TEIXEIRA TP. 2009. Distribution of guppies Poecilia reticulata (Peters, 1860) and Phalloceros caudimaculatus (Hensel, 1868) along a polluted stretch of the Paraíba do Sul River, Brazil. Brazilian J Biol 69: 41-48.

BEN-AMI F \& HELLER J. 2005. Spatial and temporal patterns of parthenogenesis and parasitism in the freshwater snail Melanoides tuberculata. J Evol Biol 18: 138-146.

BOAVENTURA MF, FERNANDEZ MA, THIENGO SC, SILVA RE \& MELO AL. 2002. Formas larvais de Trematoda provenientes de gastrópodes límnicos da microrregião Rio de Janeiro, sudeste do Brasil. Lundiana 3: 45-49.

BOGÉA TC, ORDEIRO FM \& GOUVEIA JS. 2005. Melanoides tuberculatus (Gastropoda: Thiaridae) as intermediate host of Heterophyidae (Trematoda: Digenea) in Rio de Janeiro metropolitan area, Brazil. Rev Inst Med Trop São Paulo 47: 87-90.

BRUM WM, PEREIRA MAVC, VITA GF, FERREIRA I, MELLO ER, AURNHEIMER RCM, SANAVRIA A \& PADUA ED. 2016. Parasitismo em aves silvestres e migratória da ilha da Marambaia, estado do Rio de Janeiro. Pesqui Vet Bras 36: 1101-1108.

CHAI J-Y, SOHN W, YONG T, EOM KS, MIN D, LEE MY, LIM H, INSISIENGMAY B, PHOMMASACK B \& RIM H. 2013. Centrocestus formosanus (Heterophyidae): Human Infections and the Infection Source in Lao PDR. J Parasitol 99: 531-536.

CHEN HT. 1942. The metacercaria and adult of Centrocestus formosanus (Nishigori, 1924), with notes on the natural infection of rats and cats with C. armatus (Tanabe, 1922). J Parasitol 28: 285.
CHEN J, LI Q, KONG L \& YU H. 2011. How DNA Barcodes Complement Taxonomy and Explore Species Diversity: The Case Study of a Poorly Understood Marine Fauna. PLOS ONE 6(6): e21326.

CHEN YZ, XU XL, CHEN BJ, GUO ZF, ZHEN HY \& LIN SS. 1991. First report on human infection of Centrocestus formosanus (in Fujian). Chinese J Parasitol Parasit Dis 9: 273.

CHENG EAMTC \& MALEK EA. 1974. Medical and economic malacology. New York: Academic Press Inc., 398 p.

CHUBOON S \& WONGSAWAD C. 2009. Molecular identification of larval trematode in intermediate hosts from Chiang Mai, Thailand. Southeast Asian J Trop Med Public Heal 40: $1216-1220$.

COELHO PN, FERNANDEZ MA, CESAR DAS, RUOCCO AMC \& HENRY R. 2018. Update distribution and range expansion of the gastropod invader Melanoides tuberculata (Müller, 1774) in Brazilian waters. Biolnvasions Rec 4: 405-409.

CORTÉS DA, DOLZ G, ZÚÑIGA JJR, ROCHA AEJ \& ALÁN DL. 2009. Centrocestus formosanus (Opisthorchiida: Heterophyidae) como causa de muerte de alevines de tilapia gris Oreochromis niloticus (Perciforme: Cichlidae) en el Pacífico seco de Costa Rica. Rev Biol Trop 58: 1453-1465.

DAYRAT B. 2005. Towards integrative taxonomy? Biol J Linn SOC 85: 407-415.

DE NV \& LE TH. 2011. Human infections of fish-borne trematodes in Vietnam: Prevalence and molecular specific identification at an endemic commune in Nam Dinh province. Exp Parasitol 129: 355-361.

ESCH GW, BARGER MA \& FELLIS KJ. 2002. The transmission of digenetic trematodes: Style, elegance, complexity. Integr Comp Biol 42: 304-312.

FERNANDEZ MA, THIENGO SC \& SIMONE LRL. 2003. Distribution of the introduced freshwater snail Melanoides turbeculatus (Gastropoda: Thiaridae) in Brazil. Nautilus (Philadelphia) 117: 78-82.

FREDENSBORG BL, MOURITSEN KN \& POULIN R. 2006. Relating bird host distribution and spatial heterogeneity in trematode infections in an intertidal snail - From small to large scale. Mar Biol 149: 275-283.

GJURČEVIĆ E, PETRINEC Z, KOZARIĆ Z, KUŽIR S, GJURČEVIĆ KANTURA V, VUČEMILO M \& DŽAJA P. 2007. Metacercariae of Centrocestus formosanus in goldfish (Carassius auratus L.) imported into Croatia. Helminthologia 44: 214-216.

GRAÇA RJ, FABRIN TMC, GASQUES LS, PRIOLI SMAP, BALBUENA JA, PRIOLI AJ \& TAKEMOTO RM. 2018. Topological congruence between phylogenies of Anacanthorus spp. (Monogenea: 
Dactylogyridae) and their Characiformes (Actinopterygii) hosts: A case of host-parasite cospeciation. PLOS ONE 13: e0193408.

HALL TA. 1999. BioEdit: a user-friendly biological sequence alignment editor and analysis program for Windows 95/98/NT. Nucleic Acids Symp Ser 41: 95-98.

HAN E-T, SHIN E-H, PHOMMAKORN S, SENGVILAYKHAM B, KIM J-L, RIM H-J \& CHAI J-Y. 2008. Centrocestus formosanus (Digenea: Heterophyidae) encysted in the freshwater fish, Puntius brevis, from Lao PDR. Korean I Parasitol 46: 49.

HONG SJ, HAN JH, PARK CK \& KANG SY. 1997. Intestinal pathologic findings at early stage infection by Centrocestus armatus in albino rats. Korean J Parasitol 35: 135.

HUSTON D, WORSHAM M, HUFFMAN D \& OSTRAND K. 2014. Infection of fishes, including threatened and endangered species by the trematode parasite Haplorchis pumilio (Looss, 1896) (Trematoda: Heterophyidae). Biolnvasions Rec 3: 189-194.

KOMIYA Y \& SUZUKI N. 1966. Metacercariae of trematodes of the family Heterophyidae from Japan and adjacent countries. Japanese J Parasitol 15: 208-214.

KUMAR S, STECHER G \& TAMURA K. 2016. MEGA7: Molecular Evolutionary Genetics Analysis Version 7.0 for Bigger Datasets. Mol Biol Evol 33: 1870-1874.

LOCKYER AE, OLSON PD \& LITTLEWOOD DTJ. 2003. Utility of complete large and small subunit rRNA genes in resolving the phylogeny of the Neodermata (Platyhelminthes): Implications and a review of the cercomer theory. Biol J Linn Soc Lond 78: 155-171.

MARINGÁ. 2007. Revisão do Plano de Manejo do Parque do Ingá: Educação Ambiental. Prefeitura do Município Mar. (PMM). Secr do Meio Ambiente.

MARTIN WE. 1958. The life histories of some Hawaiian Heterophyid Trematodes. J Parasitol 44: 305.

MATI VLT, PINTO HA \& MELO AL. 2013. Experimental infection of swiss and Akr/J mice with Centrocestus formosanus (Trematoda: Heterophyidae). Ver Inst Med Trop São Paulo 55(2): 122-136.

MCDERMOTT KS, ARSUFFI TL, BRANDT TM, HUSTON DC \& OSTRAND KG. 2015. Distribution and occurrence of the exotic digenetic trematode (Centrocestus formosanus), its exotic snail intermediate host (Melanoides tuberculatus), and rates of infection of fish in springs systems in western Texas. Southwest Nat 59: 212-220.
MITCHELL AJ, OVERSTREET RM, GOODWIN AE \& BRANDT TM. 2005. Spread of an exotic fish-gill trematode. Fisheries 30: 10-18.

MITCHELL AJ, SALMON MJ, HUFFMAN DG, GOODWIN AE \& BRANDT TM. 2000. Prevalence and pathogenicity of a heterophyid trematode infecting the gills of an endangered fish, the fountain darter, in two central texas spring-fed rivers. J Aquat Anim Health 12: 283-289.

NISHIGORI M. 1924. On a new trematode Stamnosoma formosanum n. sp. and its development. Taiwan Igakkai Zasshi 234: 181-228.

OLSON PD \& TKACH V V. 2005. Advances and trends in the molecular systematics of the parasitic platyhelminthes. Adv Parasitol 60: 165-243.

PAULA-ANDRADE C, PINTO HA, COSCARELLI D, VIDIGAL T \& MELO AL. 2012. The natural infection of Melanoides tuberculata (Müller, 1774) (Mollusca: Gastropoda) by Centrocestus formosanus (Nishigori, 1924) (Platyhelminthes: Trematoda) in Paranoá lake, Brasília, Brazil. Brazilian J Biol 72: 419-420.

PAVANELLI GC, EIRAS I DA C \& TAKEMOTO RM. 2002. Doenças de peixes, profilaxia, diagnóstico e tratamento. Maringá: Eduem, $311 \mathrm{p}$.

PERKINS SL, MARTINSEN ES \& FALK BG. 2011. Do molecules matter more than morphology? Promises and pitfalls in parasites. Parasitol 138: 1664-1678.

PIAZZA RS, MARTINS ML, GUIRALDELLI L \& YAMASHITA MM. 2006. Parasitic diseases of freshwater ornamental fishes commercialized in Florianópolis, Santa Catarina, Brazil. Bol do Inst Pesca 32: 51-57.

PINTO HA, MATI VLT \& MELO AL. 2013. New records and a checklist of trematodes from Butorides striata (Aves: Ardeidae). Rev Mex Biodivers 84: 1100-1110.

PINTO HA, MATI VLT \& MELO AL. 2014. Metacercarial infection of wild nile tilapia (Oreochromis niloticus) from Brazil. Sci World J 2014: 1-7.

PINTO HA \& MELO AL. 2010. Melanoides tuberculata (Mollusca: Thiaridae) as an intermediate host of Centrocestus formosanus (Trematoda: Heterophyidae) in Brazil. Rev Inst Med Trop São Paulo 52: 207-210.

PINTO HA \& MELO AL. 2011. A checklist of trematodes (Platyhelminthes) transmitted by Melanoides tuberculata (Mollusca: Thiaridae). Zootaxa 2799: 15.

PINTO HA \& MELO AL. 2012a. Infecção natural de Poecilia reticulata (Actinopterygii: Poeciliidae) por metacercárias na represa da Pampulha, Belo Horizonte, Minas Gerais, Brasil. Biol Inst Pesca 38(3): 257-264. 
PINTO HA \& MELO AL. 2012b. Metacercariae of Centrocestus formosanus (Trematoda: Heterophyidae) in Australoheros facetus (Pisces: Cichlidae) in Brazil. Rev Bras Parasitol Veterinária 21: 334-337.

PINTO HA \& MELO AL. 2013. A checklist of cercariae (Trematoda: Digenea) in molluscs from Brazil. Zootaxa 3666: 449-475.

REKHARANI Z \& MADHAVI R. 1985. Digenetic trematodes from mullets of Visakhapatnam (India). J Nat Hist 19: 929-951.

ROSENTHAL A, COUTELLE O \& CRAXTON M. 1993. Large-scale production of DNA sequencing templates by microtitre format PCR. Nucleic Acids Res 21: 173-174.

RZĄD I \& BUSSE P. 2015. Collyriclum faba (Digenea: Collyriclidae) in migrant Phylloscopus trochilus (Aves: Sylvidae) in Egypt: The first record of the parasite on the African continent. Turkish J Zool 39: 359-364.

SALGADO-MALDONADO G, AGUILAR-AGUILAR R, CABAÑASCARRANZA G, SOTO-GALERA E \& MENDOZA-PALMERO C. 2005. Helminth parasites in freshwater fish from the Papaloapan river basin, Mexico. Parasitol Res 96: 69-89.

SALGADO-MALDONADO G, RODRIGUEZ-VARGAS MI \& CAMPOSPEREZ JJ. 1995. Metacercariae of Centrocestus formosanus (Nishigori, 1924) (Trematoda) in freshwater Fishes in México and their transmission by the Thiarid Snail Melanoides tuberculata. Stud Neotrop Fauna Environ 30: 245-250.

SÁNCHEZ J, ALBA A, GARCíA E, CANTILLO J, CASTRO R \& VÁZQUEZ AA. 2018. Detected trematodes inside blue-winged teals (Spatula discors) give insights on north-south flow of parasites through Cuba during migration. Vet Parasitol Reg Stud Reports 13: 124-129.

SCHOLZ T \& SALGADO-MALDONADO G. 2000. The introduction and dispersal of Centrocestus formosanus (Nishigori, 1924) (Digenea: Heterophyidae) in Mexico: A review. Am Midl Nat 143: 185-200.

SUMUDUNI BGD, MUNASINGHE DHN \& ARULKANTHAN A. 2018. Chronological analysis of the damages caused by the metacercariae of Centrocestus formosanus in the gills of cyprinus carpio and lesions caused by the adult flukes in Ardeola ralloides: An experimental study. Int J Vet Sci Med 6: 165-171.

TAKEMOTO RM, LIZAMA M DE LOS AP, GUIDELLI GM \& PAVANELLI GC. 2004. Parasitos de organismos aquáticos: Parasitos de peixes de águas continentais. In Ranzani-Paiva MJT, Takemoto RM \& Lizama M de los AP (Eds). Sanidade de Organismos Aquáticos, São Paulo: Livraria Varela, p. 179-198.
TAMPIERI MP, CAFFARA M, DIEGOLI G, GALUPPI R, MARCER F, MATTIOLI R, MINELLI C \& RUSTANI R. 1999. Prima segnalazione in italia de Centrocestus armatus e C. formosanus (Digenea, Heterophyidae) in pesci d'acqua dolce di importazione. Boll Soc Ital di Patol Ittica 27: 27-34.

TAVECHIO LGW, GUIDELLI G \& PORTZ L. 2009. Alternatives for the prevention and control of pathogens in fish farming. Bol do Inst Pesca 35: 335-341.

THATCHER VE. 1993. Trematódeos Neotropicais. Manaus: INPA, 553 p.

THIENGO SC, FERNANDEZ MA, BOAVENTURA MF, GRAULT CE, SILVA HF, MATTOS AC \& SANTOS SB. 2001. Freshwater snails and schistosomiasis mansoni in the State of Rio de Janeiro, Brazil: I - metropolitan mesoregion. Mem Inst Oswaldo cruz 96: 177-184.

TOLLEY-JORDAN LR \& CHADWICK MA. 2012. CentrocestuS formosanus Nishigori (Asian gill-trematoda). In: Francis R.A. (Ed). A Handbook of Global Freshwater Invasive Species, Earthscan, $447 \mathrm{p}$.

VAZ JF, TELES HMS, CORREA MA \& LEITE SPS. 1986. Ocorrência no Brasil de Thiara (Melanoides) tuberculata (O.F. Muller, 1774) (Gastropoda, Prosobranchia), primeiro hospedeiro intermediário de Clonorchis sinensis (Cobbold, 1875) (Trematoda, Plathyhelmintes). Rev Saude Publica 20: 318-322.

VELÁSQUEZ LE, BEDOYA JC, AREIZA A \& VÉLEZ I. 2006. Primer registro de Centrocestus formosanus (Digenea: Heterophyidae) en Colombia. Rev Mex Biodivers 77: $119-121$.

VÉLEZ-HERNÁNDEZ EM, CONSTANTINO-CASAS F, GARCÍAMÁRQUEZ LJ \& OSORIO-SARABIA D. 1998. Gill lesions in common carp, Cyprinus carpio L., in Mexico due to the metacercariae of Centrocestus formosanus. J Fish Dis 21: 229-232.

XIMENES RF, GONÇALVES ICB, MIYAHIRA IC, PINTO HA, MELO AL \& SANTOS SB. 2016. Centrocestus formosanus (Trematoda: Heterophyidae) in Melanoides tuberculata (Gastropoda: Thiaridae) from Vila do Abraão, Itha Grande, Rio de Janeiro, Brazil. Brazilian J Biol 77: 318-322.

YOUSIF F, AYOUB M, TADROS M \& EL BARDICY S. 2016. The first record of Centrocestus formosanus (Nishigori, 1924) (Digenea: Heterophyidae) in Egypt. Exp Parasitol 168: 56-61.

\section{SUPPLEMENTARY MATERIAL}

\section{Table SI}




\section{How to cite}

CICCHETO JRM, STABILE BHM, FABRIN TMC, DE OLIVEIRA AV, TAKEMOTO RM \& DA GRAÇA RJ. 2021. The first record of Centrocestus formosanus (Trematoda: Heterophyidae) in southern Brazil supported by molecular data. An Acad Bras Cienc 93: e20191017. DOI 10.1590/00013765202120191017.

Manuscript received on August 29, 2019;

accepted for publication on April 13, 2020

\section{JULIANA R.M. CICCHETO'}

https://orcid.org/0000-0003-2264-3835

BRUNO H.M. STABILE ${ }^{2}$

https://orcid.org/0000-0002-3524-537X

THOMAZ M.C. FABRIN ${ }^{2}$

https://orcid.org/0000-0002-4529-7106

ALESSANDRA V. DE OLIVEIRA
https://orcid.org/0000-0002-1342-4545

RICARDO M. TAKEMOTO $2,4,5$

https://orcid.org/0000-0001-7592-2083

\section{RODRIGO J. DA GRAÇA}

https://orcid.org/0000-0003-4843-7319

'Programa de Pós-Graduação em Ecologia e Conservação, Universidade Federal do Paraná/UFPR, Centro Politécnico, Av. Cel. Francisco H. dos Santos, 100, Jardim das Américas, 81531-990 Curitiba, PR, Brazil

${ }^{2}$ Programa de Pós-Graduação em Ecologia de Ambientes Aquáticos Continentais, Universidade Estadual de Maringá/UEM, Av. Colombo, 5790, Jardim Universitário, 87020-900 Maringá, PR, Brazil
${ }^{3}$ Departamento de Biotecnologia, Genética e Biologia Celular, Universidade Estadual de Maringá/UEM, Av. Colombo, 5790, Jardim Universitário, 87020-900 Maringá, PR, Brazil

${ }^{4}$ Programa de Pós-Graduação em Biologia Comparada, Universidade Estadual de Maringá/UEM, Av. Colombo, 5790, Jardim Universitário, 87020-900 Maringá, PR, Brazil

${ }^{5}$ Núcleo de Pesquisas em Limnologia, Ictiologia e Aquicultura (Nupélia), Universidade Estadual de Maringá/UEM, Av. Colombo, 5790, Jardim Universitário, 87020-900 Maringá, PR, Brazil

${ }^{6}$ Departamento de Biologia, Universidade Estadual de Maringá/UEM, Av. Colombo, 5790, Jardim Universitário, 87020-900 Maringá, PR, Brazil

Correspondence to: Juliana Ciccheto

E-mail: cicchetojrm@gmail.com

\section{Author contributions}

Juliana R. M. Ciccheto and Rodrigo J. da Graça collected the data. Juliana R. M. Ciccheto and Bruno H. M. Stabile wrote the paper. Thomaz M. C. Fabrin, Bruno H. M. Stabile and Rodrigo J. da Graça performed the molecular analyzes and interpreted the data. Alessandra V. de Oliveira and Ricardo M. Takemoto provided revisions to scientific content of manuscript, access to research components, and funding. Rodrigo J. da Graça designed the work.

\section{(cc) BY}

